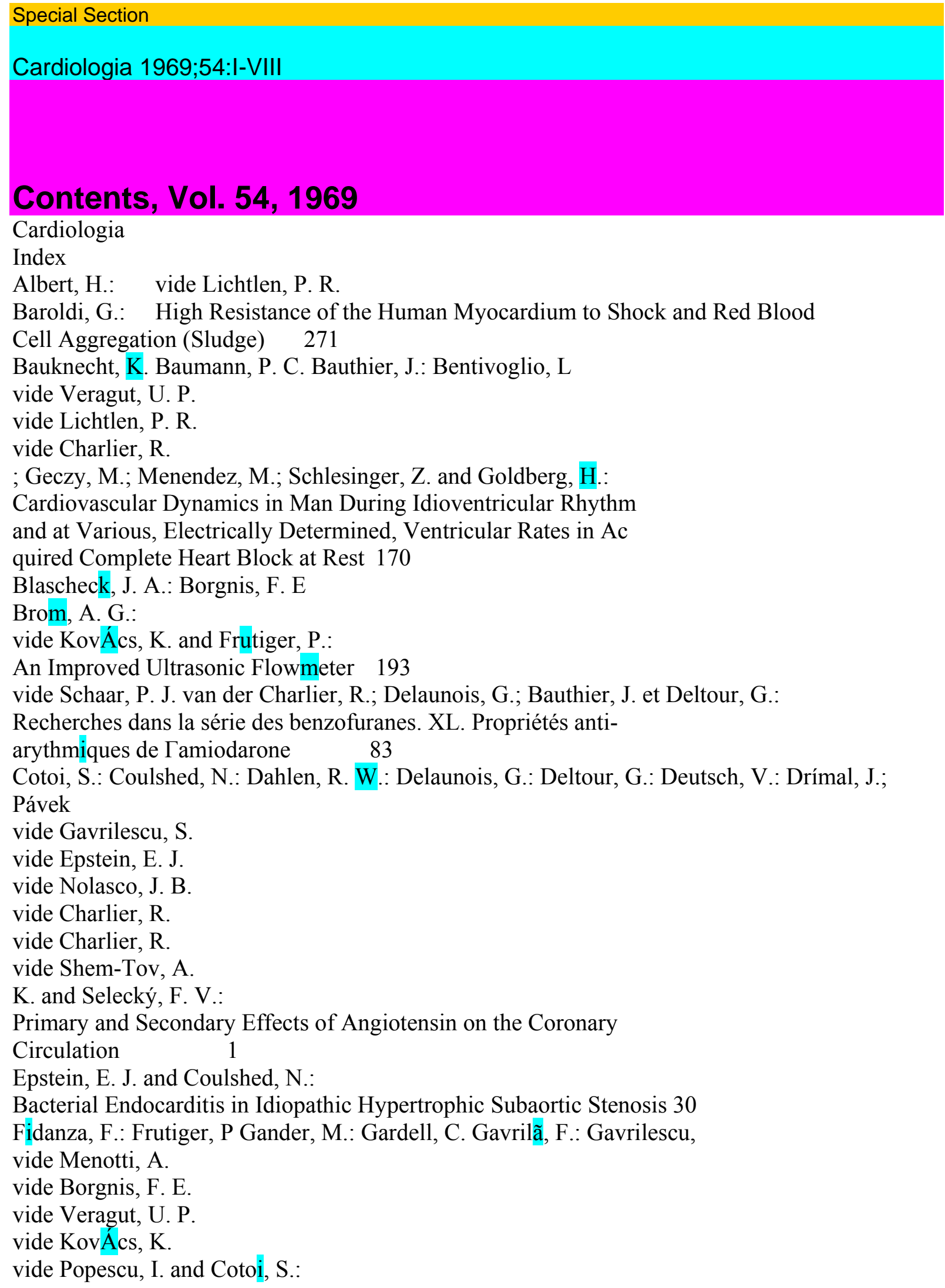


Complete Heart Block with Total Recovery in a Previously Healthy

17-Year-Old Boy 353

Geczy, M.: vide Bentivoglio, L. G.

Goetzová, J.: vide Samánek, M.

Goldberg, H.: vide Bentivoglio, L. G.

VI

Index

Günther, K. H.: vide Strangfeld, D.

Hafemeister, G.: vide Knorre, G. H. von

Halonen, P. I.: vide Virtanen, S. I.

Herles, F.: vide Jezek, V.

Hörnblad, P. Y.; Larsson, K. S. and Marsk, L.:

Studies on Closure of the Ductus Arteriosus. VII. Closure Rate and

Morphology of the Ductus Arteriosus in the Lamb 336

Ioannidis, P. J. and Tsitouris, G. C.:

Influence of Posterobasal Myocardial Infarction (PBMI) on the QRS

and T Wave Amplitude in the Limb and V6 Leads 245

Jezek, V. and Herles, F.:

Uneven Distribution of Pulmonary Arterial Wedge Pressure in

Chronic Bronchitis and Emphysema 164

Johnson, K. T.: vide Nolasco, J. B.

Jonsson, B. and Sanai, S.:

The Reliability of Diastolic Pressure Measurement in the Pulmonary

Artery as an Index of Mean Left Atrial Pressure

329

Katznelson, D.: vide Shem-Tov, A.

Kee Soon Kim : vide Randall, W. C.

Kleiman, B.: vide Savoie, L.

Knorre, G. H. von und Hafemeister, G.:

Zum Begriff der Parasystolie 129

KovÁcs, K.; Blascheck, J. A. and Gardell, C.:

Electron Microscopic Study of Myocardial Changes Produced in Rats

by the Concurrent Administration of $9 \alpha$-Fluorocortisol, Na2HP04

and Corn Oil $\quad 16$

Krajny, M.: vide Savoie, L.

Krayenbühl, H.: vide Veragut, U. P.

Larsson, K. S.: vide Hörnblad, P. Y.

Lichtlen, P. R.; Baumann, P. C. and Albert, H.:

The Role of Left Ventricular Abnormalities in Exercise-Induced Performance in Patients with

Severe Coronary Artery Disease . . . 295

Lord, P.; Sowton, E.; Resnekov, L. and Norman, J.:

The Effect of Atrial Transport on Ventricular Performance in Dogs . 343

Mäkelä, P.: $\quad$ vide Välimäki, I.

Marsk, L.: vide Hörnblad, P. Y.

Matsumura, N.: vide Nakamura, Y.

Menendez, M.: vide Bentivoglio, L. G.

Menotti, A.; Puddu, V.; Monti, M. and Fidanza, F.: 
Habitual Physical Activity and Myocardial Infarction

Monti, M.: vide Menotti, A.

Moulopoulos, S. D. and Sideris, D. A.:

Effect of Parasystole on Ventricular Response to Atrial Fibrillation.

\section{Report of a Case 257}

Nakamura, Y.; Takahashi, M.; Takei, F.; Matsumura, N.; Schölkens, B. and Sasa-

moto, H.: The Change in Coronary Vascular Resistance During Acute Induced

Hypoxemia - With Special Reference to Coronary Vascular Reserve 91

Neufeld, H. N.: vide Shem-Tov, A.

Index

VII

Nolasco, J. B.; Johnson, K. T. and Dahlen, R. W.:

Atrioventricular and Interventricular Discordance During Pulsus

Alternans in the Dog 205

Norman, J.: vide Lord, P.

Onat, T. and Zeren, E.:

Coarctation of the Abdominal Aorta. Review of 91 Cases 140

Pace, J. B.: vide Randall, W. C.

Pávek, K.: $\quad$ vide Drímal, J.

Popescu, I.; Zamfirescu-Gheorghiu, M. and Gavrilã, F.:

Contribution to the Enzymic Diagnosis of Acute Myocarditis, Myo-

cardinal Infarction and Cardiogenic Shock 278

Porstmann, W.: vide Strangfeld, D.

Puddu, V.: vide Menotti, A.

Randall, W. C.; Pace, J. B.; Wechsler, J. S. and Kee Soon Kim:

Cardiac Responses to Separate Stimulation of Sympathetic and Par-asympathetic Components of the Vagosympathetic Trunk in the Dog 104

Resnekov, L.: vide Lord, P.

Rodbard, S.: vide Takacs, L.

Roos, J. P.: vide Schaar, P. J. van der

Rutishauser, W.: vide Veragut, U. P.

Samánek, M.; Vorísková, M.; Goetzová, J. and Tuma, S.:

Local Pulmonary Blood Flow in Children with Stenosis of Pulmonary

Artery 235

Sanai, S.: $\quad$ vide Jonsson, B.

Sasamoto, H.: vide Nakamura, Y.

Savoie, L.; Krajny, M. and Kleiman, B.:

Digitoxin Induced Cardiac Necrosis and its Inhibition

Schaar, P. J. van der; Roos, J. P. and Brom, A. G.:

Clinical Diagnosis and Surgical Treatment of Ventricular Aneurysm 55

Schlesinger, Z.: vide Bentivoglio, L. G.

Schölkens, B.: vide Nakamura, Y.

Selecký, F. V.: vide Drímal, J.

Shem-Tov, A.; Yahini, J. 1·L; Deutsch, V.; Katznelson, D. and Neufeld, H. N.:

Congenital Mitral Stenosis

Sideris, D. A.: vide Moulopoulos, S. D. 
Sowton, E.: vide Lord, P.

Strangfeld, D.; Günther, K. H. and Porstmann, W.:

Cardiac Output Measurement by Continuous Infusion of Radio Jodinated Sodium Hippurate into the Left Ventricle. Comparison with

Evans Blue and with the Fick Principle in Man 262

Szám, I.; Vass, Á. and Wein, I.:

Hyperammonemia in Cor pulmonale 321

Takacs, L. and Rodbard, S.:

'Hyperemia' in the Isolated Non-Beating Dog Heart

Takahashi, M.: vide Nakamura, Y.

Takei, F.: $\quad$ vide Nakamura, Y.

Tsitouris, G. C.: vide Ioannidis, P. J.

Tuma, S.: $\quad$ vide Samánek, M.

VIII

Index

Välimäki, I. and Mäkelä, P.:

The Effect of Proximal Electrode Placement of the Central Terminal on the Chest Lead Electrocardiogram in Newborn Infants .... 158

Vass, Á.: vide Szám, I.

Veragut, U. P.; Bauknecht, K.; Gander, M.; Krayenbühl, H. and Rutishauser, W.:

Quantitation of Myocardial Contractility by Means of Harmonic

Analysis of Isovolumic Left Ventricular Pressure Pulses 217

Virtanen, S. I. and Halonen, P. I.:

Total Heart Block as a Complication of Gout

Vorísková, M.: vide Saimáner, M.

Wechsler, J. S.: vide Randall, W. C.

Wein, I.: $\quad$ vide Szám, I.

Yahini, J. H.: vide Shem-Tov, A.

Zamfirescu-Gheorghiu, M.:

vide Popescu, I.

Zeren, E.: $\quad$ vide Onat, T.

Book Reviews - Buchbesprechungen - Livres nouveaux 320,364

Varia 192, 365

Obituary 366

Index rerum ad vol. 54 